\title{
KEADILAN RESTORATIF DAN PEMBATASAN DIVERSI PADA UNDANG-UNDANG 11 TAHUN 2012 TENTANG SISTEM PERADILAN PIDANA ANAK
}

\author{
Zenny Rezania Dewantary \\ email: zennyrezania@gmail.com
}

\begin{abstract}
Since 1997 Indonesia possessed a Law specifically regulating child court (Law No. 3 of 1997). The law's perspective, however, was still based on retributive justice. This was apparent in how the court handles juvenile delinquents. To provide better protection to the handling of children before criminal courts, the government amended Law No. 3 of 1997 by Law No. 11 of 2012 re. Juvenile Court System. This new law was founded upon the theory of restorative justice and provide for diversion. Diversion is used to prevent children from being sent to prison and in general purports to improve societal condition. This article discusses problems related to the use of diversion. One recommendation offered is that diversion should be taken into consideration without discrimination, not only in the case the penal sanction is below 7 years (imprisonment) but also above this number. In deciding the need for diversion, while also taking into consideration the seriousness of the crime committed, expediency should also be a deciding factor.
\end{abstract}

Keywords:

Juvenile Court System, Diversion, Restorative Justice

\begin{abstract}
Abstrak
Sejak 1997 Indonesia memiliki UU khusus tentang pengadilan anak (Undang-Undang Nomor 3 Tahun 1997). Namun landasan pikir yang digunakan masihlah keadilan retributif (pembalasan), yakni ketika Undang-Undang ini digunakan dalam menangani anak yang berhadapan dengan hukum $(\mathrm{ABH})$. Untuk meningkatkan perlindungan hukum bagi anak (sebagai pelaku pidana: $\mathrm{ABH}$ ), maka Undang-Undang No. 3 tahun 1997 dicabut dan digantikan oleh Undang-Undang Nomor 11 Tahun 2012 tentang Sistem Peradilan Pidana Anak (UUSPPA) yang menggunakan teori keadilan restoratif melalui upaya diversi. Tujuannya adalah menghindarkan anak dari hukuman penjara secara khusus, dan perbaikan kondisi masyarakat secara umum. Tulisan ini akan mendiskusikan persoalan yang terkait dengan diversi. Satu rekomendasi penting yang dapat diajukan ialah bahwa diversi seharusnya diwajibkan tidak hanya untuk ancaman pidana di bawah 7 (tujuh) tahun tapi juga di atas 7 (tujuh) tahun tanpa pembedaan. Berat atau ringannya pidana yang dilakukan sebagai pertimbangan penegak hukum untuk diversi seharusnya didasarkan pada kemanfaatan dan tidak dibatasi oleh UUSPPA itu sendiri.
\end{abstract}

Kata kunci:

Sistem Peradilan Pidana Anak, Diversi, Keadilan Restoratif

\section{Pengantar}

Hukum dalam sebuah sistem masyarakat dapat dilihat dari 3 (tiga) fenomena. Ketiga fenomena ini adalah seimbangnya peranan antara satu dengan yang lain. Pertama, ada kekuatan-kekuatan sosial dan legal yang dengan cara 
tertentu mendesak masuk dan membentuk "hukum."1 Kemudian muncul "hukum" itu sendiri - struktur-struktur dan peraturan-peraturan. ${ }^{2}$ Ketiga, ada dampak dari hukum tersebut terhadap perilaku di dunia luarnya. ${ }^{3}$

Dalam sistem hukum pidana terdapat beberapa aliran pemidanaan. Pertama aliran pemidanaan yang mendasarkan pada teori retributivisme di mana tujuan dari pemidanaan adalah pembalasan. Pelaku pidana pantas untuk diberikan hukuman sesuai dengan tindak pidananya. Aliran yang kedua adalah aliran utilitarianisme yang melihat pada kemanfaatan dari pemidanaan itu sendiri. Sebuah pemidanaan harus mempertimbangkan faktor pada masyarakat secara menyeluruh, bukan hanya untuk pembalasan semata. Dari aliran ini terdapat teori tujuan (relatif). Dalam teori tujuan ini penekanannya adalah pada bagaimana memperbaiki atau membina si pelaku tindak pidana tersebut dan bagaimana mewujudkan ketertiban dalam masyarakat. ${ }^{4}$

Pendekatan yang kedua tersebut muncul pada Undang-Undang Nomor 11 Tahun 2012 tentang Sistem Peradilan Pidana Anak di Indonesia. Pada UUSPPA tersebut disebutkan mengenai keadilan restoratif dan upaya diversi. Kedua konsep ini tidak ada pada Undang-Undang Pengadilan Anak Nomor 3 Thun 1997 yang berlaku sebelumnya. UU Pengadilan Anak hanya mengulang apa yang diatur dalam KUHAP dan masih berprinsip retributif atau pembalasan. Sedangkan UUSPPA melalui ketentuan umumnya sudah terlihat ingin berlandaskan pada aliran pemidanaan yang melihat pada tujuan kemanfaatan dan keterlibatan aspek-aspek masyarakat guna memperbaharui struktur sosial yang mengalami peristiwa pidana.

Dalam sistem pidana anak terdapat beberapa kategori anak, yaitu anak sebagai korban, anak sebagai saksi dan anak sebagai pelaku tindak pidana atau disebut juga anak yang berhadapan dengan hukum $(\mathrm{ABH})$. Istilah $\mathrm{ABH}$ ini muncul di

\footnotetext{
${ }^{1}$ Lawrence M. Friedman, Sistem Hukum Perspektif Ilmu Sosial, Nusa Media, Bandung, 2011, hlm. 2.

2 Id.

${ }^{3}$ Id.

4 Djisman Samosir, Sekelumit tentang Penologi dan Pemasyarakatan, Nuansa Aulia, Bandung, 2012, hlm 89
} 
UUSPA. UU Pengadilan anak menyebut anak yang melakukan tindak pidana sebagai Anak Nakal.

ABH menurut SPPA adalah mereka yang sudah berusia 12 (dua belas) tahun dan belum berusia 18 (delapan belas) dan belum menikah. Untuk anak sebagai korban dan anak sebagai saksi dikategorikan sebagai mereka yang belum berusia 18 (delapan belas) dan belum menikah.

Pemerintah meningkatkan perlindungan hukum bagi anak yang terlibat dengan hukum, pertama, terlihat dengan menjadi Negara Pihak dalam Konvensi Hak-Hak Anak (Convention on the Rights of the Child) ${ }^{5}$ yang mengatur prinsip pelindungan hukum terhadap anak. Negara mempunyai kewajiban untuk memberikan pelindungan khusus terhadap anak yang berhadapan dengan hukum. Salah satu bentuk perlindungan yang dapat dilakukan Negara terhadap ABH adalah dengan memiliki instrumen hukum yang khusus mengatur tentang itu. Sebagaimana disebut dalam The Beijing Rules ${ }^{6}$ :

Member States shall endeavour to develop conditions that will ensure for the juvenile a meaningful life in the community, which, during that period in life when she or he is most susceptible to deviant behaviour, will foster a process of personal development and education that is as free from crime and delinquency as possible.

Dalam instrumen hukum nasional, perlindungan Negara atas $\mathrm{ABH}$ dalam menjalani prosedur acara pidana diatur baik langsung maupun tidak langsung dalam peraturan perundang-undangan termasuk berdasarkan Pancasila dan berlandaskan Undang-Undang Dasar Negara Republik Indonesia Tahun 1945 serta prinsip-prinsip dasar konvensi hak-hak anak, pasal 2 meliputi: ${ }^{7}$

a. Non diskriminasi

b. Kepentingan yang terbaik bagi anak adalah dalam semua tindakan yang menyangkut anak yang dilakukan oleh pemerintah, masyarakat, badan

\footnotetext{
${ }^{5}$ http://www.ohchr.org/en/professionalinterest/pages/crc.aspx diakses 2 Desember 2016

${ }^{6}$ United Nations Standard Minimum Rules For the Administration of Juvenile Justice, 96 th Plennary Meeting, November 29th 1985

7 H. R. Abdussalam dan Adri Desasfuryanto, Hukum Perlindungan Anak, PTIK, Jakarta, 2016, hlm. 3637.
} 
legislatif dan badan yudikatif, maka kepentingan yang terbaik bagi anak harus menjadi pertimbangan utama.

c. Hak untuk hidup, kelangsungan hidup dan perkembangan adalah hak asasi yang paling mendasar bagi anak yang dilindungi oleh negara, pemerintah, masyarakat, keluarga dan orang tua.

d. Penghargaan terhadap pendapat anak adalah penghormatan atas hak-hak anak untuk berpartisipasi dan menyatakan pendapatnya dalam pengambilan keputusan terutama jika menyangkut hal-hal yang mempengaruhi kehidupannya.

Dari instrumen hukum internasional dan juga landasan Negara yaitu Pancasila dan UUD 1945, perlindungan terhadap ABH diterjemahkan ke dalam UUSPPA sebagaimana disebut sebelumnya. UUSPPA menggunakan teori keadilan restoratif untuk menggantikan teori keadilan retributif. Hal tersebut diwujudkan dalam tersedianya upaya diversi yang memberi kesempatan agar sistem acara pidana biasa tidak perlu diterapkan. Sehingga bagi ABH dapat terhindar dari dampak negatif pemidanaan dan baginya dapat dicarikan alternatif penyelesaian perkara yang lebih memperhatikan kemanfaatan bagi masa depan $\mathrm{ABH}$, bagi korban serta bagi masyarakat secara umum.

Pancasila pada sila ke-4 dan ke-5 menyiratkan bahwa ciri Bangsa Indonesia adalah berlandaskan pada musyawarah dan keadilan sosial. Diversi yang merupakan metoda yang menggunakan musyawarah dan tujuan keadilan restoratif itu berada di jalur yang sama dengan keadilan sosial. Keadilan retributif pada UU Pengadilan Anak bersifat individual karena menekankan pada pembalasan semata.

Perlu dicermati dalam UUSPPA, Pasal 7 ayat (1) berbunyi,

Pada tingkat penyidikan, penuntutan, dan pemeriksaan perkara Anak di pengadilan negeri wajib diupayakan Diversi.

Ayat (2) berbunyi,

Diversi sebagaimana dimaksud pada ayat (1) dilaksanakan dalam hal tindak pidana yang dilakukan: a. diancam dengan pidana penjara di 
bawah 7 (tujuh) tahun; dan b. bukan merupakan pengulangan tindak pidana.

Pasal ini memberikan pembatasan bahwa kewajiban diversi hanya untuk perkara pidana yang memiliki ancaman pidana di bawah 7 (tujuh) tahun, artinya, untuk perkara pidana yang diancam dengan 7 (tujuh) tahun penjara atau lebih, dan/atau merupakan pengulangan tindak pidana, tidak wajib ditawarkan upaya diversi.

Pembatasan kewajiban diversi dengan dasar masa ancaman pidana tidak sejalan dengan tujuan diversi itu sendiri. Pasal 9 ayat (1) yang berbunyi,

Penyidik, Penuntut Umum, dan Hakim dalam melakukan Diversi harus mempertimbangkan: a. kategori tindak pidana; b. umur Anak; c. hasil penelitian kemasyarakatan dari Bapas; dan d. dukungan lingkungan keluarga dan masyarakat. (2) Kesepakatan

Kemudian Pasal 9 ayat (2) berbunyi,

Kesepakatan Diversi harus mendapatkan persetujuan korban dan/atau keluarga Anak Korban serta kesediaan Anak dan keluarganya, kecuali untuk: a. tindak pidana yang berupa pelanggaran; b. tindak pidana ringan; c. tindak pidana tanpa korban; atau d. nilai kerugian korban tidak lebih dari nilai upah minimum provinsi setempat.

Pasal tersebut menegaskan bahwa penerapan diversi adalah wajib dengan memperhatikan faktor-faktor yang muncul dalam situasi penyelesaian tindak pidana yang bersangkutan. Jadi, penegak hukum dalam segala tingkatan proses acara pidana wajib untuk menawarkan upaya diversi terlebih dahulu. Baru kemudian tetap mempertimbangkan faktor-faktor yang timbul dalam prosesnya, misalnya tidak tercapai kesepakatan antara pihak korban dengan pihak pelaku.

Sedangkan, isi Pasal 7 ayat (2) dengan sendirinya menutup kesempatan diversi bagi tindak pidana dengan ancaman hukuman penjara 7 (tahun) atau lebih. Penegak hukum tidak wajib untuk menawarkan upaya diversi untuk jenis kejahatan yang demikian. Diversi yang wajib pun, tetap bergantung pada kesepakatan pihak apakah berkehendak untuk menggunakan jalur diversi atau tidak. Sifat wajib yang dimaksud UUSPPA adalah kewajiban bagi penegak hukum untuk menawarkan 
upaya ini. Mengenai apakah kemudian diversi akan ditempuh atau tidak tetap tergantung para pihak. Hal ini menunjukkan bahwa kewajiban diversi dalam UUSPPA adalah kewajiban diversi terbatas.

Anak yang melakukan tindak pidana dengan ancaman pidana penjara 7 (tujuh) tahun atau lebih, atau mengulangi tindak pidana, berarti anak tersebut memerlukan penanganan yang lebih komprehensif. Koreksi perlu dilakukan secara hati-hati dan bertahap dengan melibatkan tenaga ahli anak. Dalam hal ini justru diversi tepat untuk digunakan bagi anak yang bersangkutan. Atas rgumen tersebut maka pembatasan dengan dasar ancaman masa penjara 7 (tujuh) tahun menjadi tidak relevan.

Dari ilustrasi di atas perlu dilakukan kajian berjudul Teori Keadilan Restoratif dan Masalah Pengaturan Diversi pada Undang-Undang Nomor 11 Tahun 2012 tentang Sistem Peradilan Pidana Anak.

\section{Sistem Peradilan Pidana Anak Indonesia}

Pasal 1 Convention on the Rights of the Child memberikan definisi dari anak, yaitu "...a child means every human being below the age of eighteen years unless under the law applicable to the child, majority is attained earlier." ${ }^{8}$ Atau anak adalah setiap orang dibawah usia 18 tahun kecuali jika hukum yang berlaku terhadap anak, kedewasaan telah dicapai terlebih dahulu.

Undang-Undang Nomor 39 Tahun 1999 tentang Hak Asasi Manusia menjelaskan bahwa anak merupakan bagian dari kelompok rentan. Setiap orang yang termasuk kelompok masyarakat yang rentan berhak memperoleh perlakuan dan perlindungan lebih berkenaan dengan kekhususannya. ${ }^{9}$ UU HAM juga menyebutkan bahwa setiap anak berhak atas perlindungan oleh orang tua, keluarga, masyarakat, dan negara dan bahwa hak anak adalah hak asasi manusia

8 Convention on the Rights of the Child, Adopted and opened for signature, ratification and accession by General Assembly resolution 44/25 of 20 November 1989 entry into force 2 September 1990, in accordance with article 49

9 Undang-Undang R.I Nomor 39 Tahun 1999, Hak Asasi Manusia, L.N.R.I Tahun 1999 No. 165, Pasal 5 ayat (3) 
dan untuk kepentingannya hak anak itu diakui dan dilindungi oleh hukum bahkan sejak dalam kandungan. ${ }^{10}$ Pun halnya bagi anak yang terlibat dengan hukum acara pidana.

Sebelum terdapat UU yang khusus mengatur mengenai acara pidana untuk anak, hal tentang pidana dan pemidanaan untuk anak berlandaskan pada Kitab Undang-Undang Hukum Pidana (KUHP), Kitab Undang-Undang Hukum Acara Pidana (KUHAP) dan sistem hukum penitensier Indonesia. Hukum penitensier disebut keseluruhan dari norma-norma yang mengatur lembaga pidana atau pemidanaan, lembaga penindakan dan lembaga kebijaksanaan yang telah diatur oleh pembentuk undang-undang di dalam hukum pidana materiil.11

Anak dapat masuk ke dalam ruang sistem pidana saat ia menjadi korban tindak pidana, saksi dalam tindak pidana, dan saat menjadi pelaku tindak pidana. KUHP mengatur mengenai tindak pidana yang dilakukan oleh mereka yang belum berumur 16 tahun. Variasi hukuman yang diberikan KUHP bagi anak belum berumur 16 tahun adalah:

- Dikembalikan kepada orang tuanya tanpa pidana apapun;

- Diserahkan kepada Pemerintah (Rumah Pendidikan Negara) tanpa pidana apapun;

- Pidana.

Prinsip yang diaplikasikan dalam pemidanaan anak pada era KUHP adalah konsep mengenai pemidanaan terhadap anak mengacu pada pemahaman bahwa, terhadap anak di bawah 10 tahun perlu dipertimbangkan tidak adanya unsur schuld dalam perbuatan si anak. Hal ini dengan menilai bahwa anak di bawah usia 10 tahun belum memiliki pemahaman dan pertanggungjawaban atas apa yang dia perbuat. Sehingga, sejalan dengan konsep dolus dan culpa dalam menentukan suatu tindak pidana, bagi pelaku berusia kurang dari 10 tahun dianggap bahwa unsur schuld itu tidak ada dan dapat dijadikan dasar penghapus pidana.

\footnotetext{
10 Id, Pasal 52 ayat (1)(2)

11 P.A.F. Lamintang dan Theo Lamintang, Hukum Penitensier Indonesia, Sinar Grafika, Jakarta, 2012, hlm. 7.
} 
Bagi pelaku anak berusia di atas 10 tahun, hakim akan menilai apakah yang bersangkutan mampu memahami perbuatannya dan apakah ia cukup cakap dalam mempertanggungjawabkan perbuatannya. Jika si anak ternyata level mentalitasnya masih seperti usia di bawah 10 tahun maka baginya tidak diberlakukan pidana penjara melainkan dapat diubah, si anak akan mendapatkan pendidikan di panti sosial atau lembaga pendidikan swasta maupun milik negara. Sedangkan jika anak sudah dianggap cakap, maka baginya akan dipidana. ${ }^{12}$

Berlakunya Undang-Undang Nomor 3 Tahun 1997 tentang Pengadilan Anak mengesampingkan aturan KUHP mengenai pidana anak. Pasal-pasal dalam UU Pengadilan Anak pada intinya masih menggunakan pendekatan retributif (pembalasan). Undang-Undang ini mengatur mengenai jenis-jenis pertanggungjawaban bagi Anak Nakal, istilah untuk anak yang melakukan tindak pidana.

Dalam Undang-Undang ini diatur batas usia Anak Nakal adalah mereka yang berumur minimal 8 (delapan) tahun sampai dengan belum berusia 18 (delapan belas) tahun dan/atau belum menikah. Jika dibandingkan dengan UUSPPA, di mana Anak yang Berhadapan dengan Hukum (ABH) adalah anak berusia 12 (dua belas) sampai dengan belum berusia 18 (delapan belas), maka UU Pengadilan Anak membuka ruang lebih luas bagi Anak Nakal untuk masuk ke dalam sistem pemidanaan dan menerima hukuman penjara.

UU Pengadilan Anak pun tidak mengatur bahwa penegak hukum yang menangani perkara Anak Nakal harus mengikuti pelatihan teknis bidang peradilan anak. Hal-hal yang demikian kemudian dianggap tidak sesuai lagi dengan tujuan perlindungan hukum bagi anak yang menginginkan suatu konsep penanganan perkara pidana anak dengan mempertimbangkan perlindungan hukum atas hak dari anak sebagai pelaku. Sasaran lain juga adalah proses acara pidana yang tidak hanya membalas perbuatan pelaku, tapi juga memperbaiki (to restore) tatanan

12 Id., hlm., 2. 
masyarakat secara umum sehingga mampu mencegah peningkatan kriminal secara umum dan mencegah dilakukannya tindak pidana oleh seseorang secara khusus.

UUSPPA berusaha menjawab keinginan perlindungan hukum tersebut dengan memasukkan fasilitas berupa upaya diversi yang pada dasarnya diwajibkan untuk diupayakan oleh penegak hukum dalam tiap tingkat pemeriksaan.

Menggantikan retributive justice, UUSPPA menerapkan restorative justice. Hal ini dicantumkan pada Pasal 1 angka 6 UU tersebut. Prinsip keadilan restoratif ini diwujudkan dengan upaya diversi, yang diatur pada Pasal 1 angka 7. Diversi adalah pengalihan penyelesaian perkara Anak dari proses peradilan pidana ke proses di luar peradilan pidana. Melalui diversi dimungkinkan proses penyelesaian acara pidana melalui musyawarah antar pihak-pihak terkait.

Latar belakang terbitnya UUSPPA adalah guna menyempurnakan perlindungan hukum bagi anak yang terlibat dalam sistem peradilan pidana, yang mana tidak ada pada UU Pengadilan Anak sebelum UUSPPA. Hal ini juga merupakan kewajiban Negara sebagai pihak dalam Konvensi Hak-Hak Anak (Convention on the Rights of the Child) ${ }^{13}$.

\section{Keadilan Restoratif}

Undang-Undang Sistem Peradilan Pidana Anak (UUSPPA) Nomor 11 Tahun 2012 memberikan definisi mengenai keadilan restoratif (restorative justice) pada Pasal 1 angka 6 berbunyi,

Keadilan Restoratif adalah penyelesaian perkara tindak pidana dengan melibatkan pelaku, korban, keluarga pelaku/korban, dan pihak lain yang terkait untuk bersama-sama mencari penyelesaian yang adil dengan menekankan pemulihan kembali pada keadaan semula, dan bukan pembalasan.

Bagir Manan, dalam tulisannya menguraikan tentang substansi "restorative justice" yang berisi prinsip-prinsip, antara lain: "Membangun partisipasi bersama antara pelaku, korban, dan kelompok masyarakat menyelesaikan suatu peristiwa

${ }^{13}$ United Nations Standard Minimum Rules For the Administration of Juvenile Justice, $96^{\text {th }}$ Plennary Meeting, November 29th 1985 
atau tindak pidana. Menempatkan pelaku, korban, dan masyarakat sebagai "stakeholders" yang bekerja bersama dan langsung berusaha menemukan penyelesaian yang dipandang adil bagi semua pihak (win-win solutions)”.14

Prinsip keadilan restoratif yang pada dasarnya merupakan upaya pengalihan dari proses peradilan pidana menuju penyelesaian secara musyawarah, tidak dapat diterapkan pada semua jenis atau tingkatan pidana. Akan tetapi dalam tindak pidana tertentu, penerapan prinsip ini boleh dikatakan jauh lebih efektif dibandingkan proses peradilan pidana yang konvensional. ${ }^{15}$

Prinsip keadilan restoratif di Indonesia mulai diterapkan pada sistem peradilan anak. Melalui keadilan restoratif, suatu tindak pidana dianggap sebagai penyakit yang perlu disembuhkan, bukan hanya tindakan melanggar hukum semata. Teori keadilan retributif mampu mengakomodasi pemahaman bahwa tindak pidana hanya merupakan pelanggaran hukum. Sedangkan jika ia dianggap sebagai penyakit yang harus disembuhkan, maka penanganannya haruslah holistik, komprehensif, melibatkan semua unsur yang tersentuh oleh tindak pidana tersebut. Dalam hal ini, keadilan restoratif merupakan pendekatan yang dapat digunakan.

Sepaham dengan itu, adalah teori keadilan dari John Rawls dan juga keadilan yang dianut oleh Pancasila. Rawls melihat kepentingan utama keadilan adalah (1) jaminan stabilitas hidup manusia, dan (2) keseimbangan antara kehidupan pribadi dan kehidupan bersama ${ }^{16}$ Pemikiran keadilan John Rawl merupakan pemikiran keadilan sosial yang dapat diterapkan dalam proses penegakan hukum. Di dalam proses penegakan hukum atas suatu tindakan kejahatan tentu harus dilihat akar persoalan tindak kejahatan itu sendiri apakah dipengaruhi oleh struktur sosial yang tidak adil. Dalam kasus demikian tentu tindakan penegakan hukum baru dapat dikatakan adil jika mempertimbangkan kondisi dan struktur sosial. ${ }^{17}$

\footnotetext{
14 http://www.bphn.go.id/data/documents/laporan_akhir_pengkajian_restorative_justice_anak pdf diakses 29 November 2016

15 https://ditreskrimsuspoldakalsel.blogspot.co.id/2013/07/keadilanrestoratif-dalam-penegakan. html diakses 29 November 2016

16 Id

17 Id
} 
Pancasila sebagai landasan idea Bangsa Indonesia menyatakan dalam sila ke5, Keadilan Sosial Bagi Seluruh Rakyat Indonesia. Pernyataan itu menunjukkan bahwa prinsip keadilan yang digunakan dalam struktur dan tatanan masyarakat Indonesia adalah keadilan dalam konteks masyarakat, bukan keadilan yang individualistis.

Hasilnya, dalam tatanan hukum acara pidana bagi anak, keadilan restoratif dapat digunakan untuk mencapai tujuan pemidanaan yang berusaha menyembuhkan $\mathrm{ABH}$ dan menyembuhkan kondisi sosial yang terinfeksi oleh peristiwa pidana.

Perwujudan dari keadilan restoratif adalah melalui upaya diversi sebagaimana terdapat dalam UUSPPA.

\section{Diversi}

Sejalan dengan diberlakukannya UU SPPA, Pemerintah mengeluarkan Peraturan Pelaksana tentang diversi melalui Peraturan Pemerintah Republik Indonesia Nomor 65 tahun 2015 Tentang Pedoman Pelaksanaan Diversi dan Penanganan Anak yang Belum Berumur 12 (Dua Belas) Tahun. Kemudian melalui PERMA RI Nomor 4 Tahun 2014 tentang Pedoman Pelaksanaan Diversi dalam Sistem Peradilan Pidana Anak, dalam Bab II dinyatakan bahwa diversi adalah wajib diupayakan.

Serangkaian peraturan tersebut pada intinya mengatakan bahwa diversi adalah proses penyelesaian perkara pidana anak melalui non-peradilan, yaitu melalui proses musyawarah di luar pengadilan.

Pengaturan diversi pada UUSPPA terdapat pada bab tersendiri yaitu Bab II tentang Diversi mulai dari Pasal 6 hingga Pasal 15. Lebih lanjut, pedoman pelaksanaan diversi diatur dalam Peraturan Pemerintah Nomor 65 Tahun 2015 tentang Pedoman Pelaksanaan Diversi dan Penanganan Anak yang Belum Berumur 12 (Dua Belas) Tahun. Mahkamah Agung juga mengeluarkan PERMA terkait diversi yaitu PERMA nomor 4 Tahun 2014 tentang Pedoman Pelaksanaan Diversi dalam Sistem Peradilan Pidana Anak. 
Pada UUSPPA terdapat pengaturan yang menjadi pokok dalam tulisan ini, yaitu yang terdapat dalam Pasal 7 ayat (2) poin a, yang berbunyi,

Diversi sebagaimana dimaksud pada ayat (1) dilaksanakan dalam hal tindak pidana yang dilakukan: a. diancam dengan pidana penjara di bawah 7 (tujuh) tahun.

Kriteria 7 (tujuh) tahun merupakan kesepakatan di mana angka tersebut merupakan lama ancaman penjara yang tepat dijadikan batas pemisah antara wajibdiversi dan tidak wajib-diversi. Jika kurang dari 7 (tujuh) tahun, maka akan sedikit jenis pidana yang diwajibkan melakukan diversi. ${ }^{18}$ Sementara UUSPPA berkeinginan untuk membuka upaya diversi seluas-luasnya.

Ketentuan demikian artinya, bagi tindak pidana dengan ancaman pidana penjara 7 (tujuh) tahun atau lebih tidak wajib melakukan diversi. Berarti bagi tindak pidana pelakunya akan diperiksa di pengadilan melalui prosedur acara pidana konvesional.

Kembali pada prinsip keadilan restoratif yang menginginkan penyembuhan yang holistik terhadap penyakit tindak pidana. Juga, di Indonesia terdapat kebutuhan untuk mengurangi peningkatan jumlah terpidana anak di Indonesia. Menurut data KPAI (Komisi Perlindungan Anak Indonesia), anak-anak yang menjalani hukuman penjara atau tahanan tiap tahun berjumlah sekitar 6000 orang anak. ${ }^{19}$

Di satu sisi, batas 7 (tujuh) tahun yang memisahkan wajib-diversi dan yang tidak menunjukkan keinginan untuk kepastian hukum untuk tindak pidana yang dianggap berat (menurut undang-undang) atau merupakan pengulangan tindak pidana, sekalipun pelakunya adalah anak. Di sisi lain, untuk sejalan dengan keadilan restoratif, upaya diversi diwajibkan di tiap level pemeriksaan. Artinya diversi adalah wajib, tapi wajib terbatas.

\footnotetext{
${ }^{18}$ Ani Triwati, Rekonstruksi Sistem Peradilan Pidana Anak dalam Idealisme Nilai Keadilan Pancasila, Universitas Semarang, disampaikan dalam Konferensi Asosiasi Filsafat Hukum Indonesia (AFHI) ke-6 tanggal 16-19 November di Universitas Pasundan, Bandung.

${ }^{19} \mathrm{http}$ ///icjr.or.id/panduan-praktis-untuk-anak-yang-berhadapan-dengan-hukum/ diakses pada 29 November 2016
} 
Pembatasan lain terlihat pula pada Pasal 9 ayat (2) UUSPPA yang berbunyi,

(2) Kesepakatan Diversi harus mendapatkan persetujuan korban dan/atau keluarga Anak Korban serta kesediaan Anak dan keluarganya, kecuali untuk: a. tindak pidana yang berupa pelanggaran; b. tindak pidana ringan; c. tindak pidana tanpa korban; atau d. nilai kerugian korban tidak lebih dari nilai upah minimum provinsi setempat.

Artinya, bagi tindak pidana kecuali yang dikecualikan dalam pasal tersebut, kewajiban diversi hanya sampai pada pengupayaannya oleh penegak hukum di level pemeriksaan terkait. Diversi adalah wajib diupayakan, tapi pelaksanaannya, apakah akan ditempuh diversi atau tidak, tergantung kesepakatan dari pihak pelaku dan korban. Dalam hal ini sangat terlihat diversi pada prinsipnya adalah wajib, tapi wajib terbatas.

\section{Aspek Hukum Acara Pidana dan Teori Pemidanaan}

Hukum acara pidana Indonesia, atau disebut juga sebagai hukum pidana formal, formeel strafrecht atau strafprocesrecht, mengacu kepada Undang-Undang Nomor 8 Tahun 1981 (LNRI 1981-76; TLNRI 3209) atau disebut Kitab UndangUndang Hukum Acara Pidana (KUHAP). KUHAP diundangkan pada tanggal 31 Desember 1981. Sedangkan sistem hukum pidana materil, mengacu kepada Kitab Undang-Undang Hukum Pidana (KUHP) dan undang-undang lain di luar KUHP yang terkait pidana.

Hukum Acara Pidana menurut Lilik Mulyadi ${ }^{20}$ dapat dikatakan sebagai berikut:

- Peraturan Hukum yang mengatur, menyelenggarakan dan mempertahankan eksistensi ketentuan Hukum Pidana Materiel (Materiel Strafrecht) guna mencari, menemukan dan mendapatkan kebenaran materiel atau kebenaran yang sesungguhnya.

- Peraturan hukum yang mengatur bagaimana cara dan proses pengambilan putusan oleh hakim.

- Peraturan hukum yang mengatur tahap pelaksanaan terhadap putusan hakim yang telah diambil.

\footnotetext{
${ }^{20}$ Lilik Mulyadi, Hukum Acara Pidana Normatif, Teoretis, Praktik dan Permasalahannya, Alumni, Bandung, 2007, hlm. 7-9.
} 
Moeljatno mengatakan bahwa hukum pidana tidak hanya membahas tentang dasar-dasar dan aturan-aturan tentang perbuatan-perbuatan yang dilarang disertai ancaman berupa pidana tertentu, tentang menentukan kapan dan dalam hal apa dikenakannya pidana yang diancamkan, tapi juga mengatur tentang menentukan dengan cara bagaimana pengenaan pidana itu dapat dilaksanakan apabila ada orang yang disangka telah melanggar larangan tersebut. ${ }^{21}$

Sistem peradilan pidana Indonesia terbagi ke dalam 5 institusi yang bersama-sama sebagai sub sistem peradilan pidana menegakkan dan mempertahankan seluruh alur beracara pidana. Tidak hanya itu, sub sistem peradilan pidana juga berfungsi pengayoman bagi seluruh aspek masyarakat Negara Indonesia. 5 institusi tersebut adalah:

- Lembaga Kepolisian (Undang-Undang Nomor 2 Tahun 2002)

- Kejaksaan (Undang-Undang Nomor 16 Tahun 2004)

- Pengadilan (Undang-Undang Nomor 8 Tahun 2004, UndangUndang Nomor 49 Tahun 2009)

- Lembaga Pemasyarakatan (Undang-Undang Nomor 12 Tahun 1995)

- Advokat (Undang-Undang Nomor 18 Tahun 2003)

Hal-hal mengenai pidana dan pemidanaan ini diatur dalam sistem hukum yang disebut sebagai sistem hukum penitensier.

Hukum penitensier pada dasarnya bicara tentang: ${ }^{22}$

- bilamana suatu pidana dapat dijatuhkan bagi seorang pelaku,

- jenis pidana yang bagaimanakah yang dapat dijatuhkan bagi pelaku tersebut,

- untuk berapa lama pidana dapat dijatuhkan atau berapa besarnya pidana denda yang dapat dijatuhkan,

- dengan cara yang bagaimanakah pidana harus dilaksanakan.

Bemmelen mengartikan hukum penitensier atau penitentiaire recht sebagai het racht betreffende doel, werking en organisatie der strafinstituten. Artinya: Hukum

\footnotetext{
${ }^{21}$ Lihat Moeljatno, Asas-Asas Hukum Pidana, Rineka Cipta, Jakarta, 2008, hlm. 1.

${ }^{22}$ Supra no. 5, hlm. 1
} 
yang berkenan dengan tujuan, daya kerja, dan organisasi dari lembaga-lembaga pemidanaan. ${ }^{23}$

Berbicara tentang pemidanaan maka pembahasan akan sampai pada teori pemidanaan. Adapun terkait tujuan dari pemidanaan ada beberapa karakteristik, diantaranya: ${ }^{24}$

- Reformation, yaitu memperbaiki atau merehabilitasi penjahat menjadi orang baik dan berguna bagi masyarakat.

- Restraint, yaitu mengasingkan pelanggar dari masyarakat sehingga timbul rasa aman masyarakat

- Retribution, yaitu pembalasan terhadap pelanggar karena telah melakukan kejahatan

- Deterrence, yaitu menjera atau mencegah sehingga baik terdakwa sebagai individual maupun orang lain yang potensi menjadi penjahat akan jera atau takut untuk melakukan kejahatan, melihat pidana yang dijatuhkan kepada terdakwa.

Rancangan KUHP tahun 2013 mencantumkan tentang tujuan pemidanaan. Pasal 54 R-KUHP 2013 berbunyi,

(1) Pemidanaan bertujuan:

a) mencegah dilakukannya tindak pidana dengan menegakkan norma hukum demi pengayoman masyarakat;

b) memasyarakatkan terpidana dengan mengadakan pembinaan sehingga menjadi orang yang baik dan berguna;

c) menyelesaikan konflik yang ditimbulkan oleh tindak pidana, memulihkan keseimbangan, dan mendatangkan rasa damai dalam masyarakat; dan

d) membebaskan rasa bersalah pada terpidana.

Jika ditarik dari beberapa sifat tujuan pidana tersebut, dapat dipahami tujuan pidana menurut beberapa teori. Berikut ini adalah teori-teori mengenai tujuan pemidanaan: ${ }^{25}$

\footnotetext{
${ }^{23}$ Supra no 5, hlm. 2

${ }^{24}$ Sugi Arto, Dasar dan Tujuan Pemidanaan, http://artonang.blogspot.co.id/2015/02/dasar-dantujuan-pemidanaan.html diakses 15 Agustus 2016

${ }^{25}$ Lihat Fajrin Recht, Pidana dan Pemidanaan, http://kitabpidana.blogspot.co.id/2012/04/pidanadan-pemidanaan.html diakses 15 Agustus 2016
} 
- Teori absolut/retributif/pembalasan (lex talionis): hukum adalah sesuatu yang harus ada sebagai konsekuensi dilakukannya kejahatan, dengan demikian orang yang salah harus dihukum

- Teori relatif/tujuan (utilitarian): penjatuhan hukuman harus memiliki tujuan tertentu, bukan hanya sekadar sebagai pembalasan. Hukuman pada umumnya bersifat menakutkan, oleh karena itu hukum sebaiknya bersifat merehabilitasi/memperbaiki karena pelaku kejahatan sesungguhnya adalah orang yang sakit moral sehingga harus diobati. Dalam hal ini hukum sebagai treatment dan pembinaan. Tujuan lain yang hendak dicapai merupakan prevensi. Prevensi umum artinya hukuman dijatuhkan sebagai pencegahan bagi masyarakat umum agar tidak mencontoh perbuatan atau kejahatan yang telah dilakukan. Prevensi khusus artinya bagi pelaku sendiri agar tidak mengulang perbuatan jahat serupa maupun perbuatan jahat lain. Selain dua tujuan tadi, termasuk dalam teori ini adalah pemidanaan sebagai sarana perlindungan bagi masyarakat lain agar merasa aman, terlindungi dan tidak menjadi korban kejahatan.

- Teori gabungan: gabungan kedua teori di atas sehingga pemidanaan bertujuan sebagai pembalasan, juga sebagai upaya prevensi, merehabilitasi pelaku, dan melindungi masyarakat.

Berdasarkan uraian tentang tujuan pemidanaan di atas maka tujuan pemidanaan yang sesuai dengan keadilan restoratif adalah teori relatif/tujuan (utilitarian). Hal tersebut juga sejalan dengan pemikiran keadilan sosial john Rawls dan juga keadilan sosial dalam Pancasila.

Keadilan restoratif sampai saat ini diterapkan pada sistem peradilan pidana anak, sedangkan untuk sistem peradilan pidana umum masih menggunakan pola konvensional. Walau demikian. seandainya hukum pidana digunakan, sehingga sanksi pidana diterapkan, tujuan pemidanaan utama yang harus dipertimbangkan bukannya rehabilitasi dan resosialisasi terpidana, melainkan justru efek moral dan 
pencegahan dari sanksi pidana. ${ }^{26}$ Sistem peradilan pidana konvensional menimbulkan masalah antara lain overcapacity pada Lembaga Pemasyarakatan (Lapas).

Untuk melihat seberapa besar permasalahan overcapacity dapat dilihat melalui tabel dibawah ini :27

$\begin{array}{lllll}\text { Jumlah } & \text { Des 2012 } & \text { Des 2013 } & \text { Des 2014 } & \text { Jan 2015 } \\ \text { Tahanan } & 48.309 & 51.293 & 52.922 & 53,014 \\ \text { Narapidana } & 102.379 & 108.668 & 110.482 & 111.845 \\ \text { UPT } & 440 & 459 & 463 & 464 \\ \text { Kapasitas } & 102.040 & 107.359 & 109.573 & 110.098 \\ \text { Overcapacity (\%) } 148 \% & 149 \% & 149 \% & 150 \%\end{array}$

Tabel 1. Perbandingan UPT, Kapasitas, dan Jumlah Tahanan+Narapidana

Sampai dengan tahun 2015, dari 33 provinsi di Indonesia, hanya 6 provinsi yang tidak mengalami overkapasitas, yaitu Provinsi D.I Yogyakarta, Maluku, Maluku Utara, Papua, Papua Barat, dan Sulawesi Barat. ${ }^{28}$ Terkait dengan overcapacity ini adalah penempatan tahanan dan narapidana anak yang pada beberapa kejadian masih ditempatkan bersamaan atau satu komplek dengan tahanan dan narapidana dewasa.

\section{Aspek Hukum Acara Pidana Anak}

UU Pengadilan Anak yang lama (UU No. 3 Tahun 1997) tidak mengenal konsep diversi dan keadilan restoratif. UU tersebut merupakan seperangkat aturan yang mengatur proses pidana selayaknya bagi pelaku dewasa namun dikhususkan bagi pelaku anak. Pelaku anak tetap masih dianggap sebagai pelaku kejahatan dewasa versi mini. Dalam UU ini belum terdapat alternatif tindakan bagi pelaku anak selain melalui proses persidangan pengadilan sehingga penjatuhan pidana masih merupakan pilihan populer dan bukanlah sebagai ultimum remedium.

\footnotetext{
${ }^{26}$ Muladi dan Barda Nawawi Arief, Bunga Rampai Hukum Pidana, Alumni, Bandung, 2007), hlm. 5.

${ }^{27}$ Erasmus A.T. Napitupulu, Over kapasitas Lapas dan Rutan: Jumlah Penghuni dan Masalah utama, http://www.hukumpedia.com/erasmus70/over-kapasitas-lapas-dan-rutan-jumlah-penghuni-danmasalah-utama Diakses 9 Agustus 2016

${ }^{28}$ Lihat http://smslap.ditjenpas.go.id/public/grl/current/monthly diakses 15 Agustus 2016
} 
Dengan adanya UU SPPA, maka hal-hal yang dirasa kurang tepat dalam menangani perkara anak melalui UU Pengadilan Anak No. 3 Tahun 1997 dapat diperbaharui. UU SPPA menjadi lex specialis dalam menangani perkara hukum yang melibatkan anak. Bersama-sama dengan UU SPPA dan KUHAP, perlakuan terhadap anak juga menjadi perhatian Undang-Undang Perlindungan Anak. Dalam UndangUndang No. 23 Tahun 2002 tentang perlindungan anak, disebutkan bahwa penyelenggaraan perlindungan anak berasaskan Pancasila dan berlandaskan Undang-Undang Dasar Negara Republik Indonesia Tahun 1945 serta prinsip-prinsip dasar konvensi hak-hak meliputi (pasal 2):29

a. Non diskriminasi.

b. Kepentingan yang terbaik bagi anak adalah dalam semua tindakan yang menyangkut anak yang dilakukan oleh pemerintah, masyarakat, badan legislatif dan badan yudikatif, maka kepentingan yang terbaik bagi anak harus menjadi pertimbangan utama.

c. Hak untuk hidup, kelangsungan hidup dan perkembangan adalah hak asasi yang paling mendasar bagi anak yang dilindungi oleh negara, pemerintah, masyarakat, keluarga dan orang tua.

d. Penghargaan terhadap pendapat anak adalah penghormatan atas hak-hak anak untuk berpartisipasi dan menyatakan pendapatnya dalam pengambilan keputusan terutama jika menyangkut hal-hal yang mempengaruhi kehidupannya.

Secara prinsipil UUSPPA sudah memberikan ruang untuk metode alternatif penyelesaian perkara pidana anak yang lebih berasaskan kemanfaatan bagi anak dan seluruh sistem masyarakat yang terlibat, melalui penerapan teori keadilan restoratif dan upaya diversi. Dalam perumusannya, terdapat kelemahan yaitu dalam hal kontradiksi antara keinginan mewajibkan upaya diversi seluas-luasnya namun juga membatasi kewajiban dari penerapan diversi itu melalui UUSPPA sendiri.

\section{Masalah Pengaturan Diversi dalam UUSPPA}

Diversi wajib diupayakan oleh setiap Penyidik, Penuntut Umum dan Hakim. Keadilan restoratif yang merupakan prinsip dalam meyelesaikan perkara pidana

${ }^{29}$ Supra no 4, hlm 36-37 
anak dikatakan dapat dicapai dengan menggunakan proses diversi. Dengan ini pemidanaan penjara dapat dihindari sedapat mungkin bagi terpidana anak dan dapat dicari penyelesaian perkara yang lebih progresif bagi anak, keluarga si anak, korban dan juga masyarakat.

Dengan hadirnya UU SPPA menggantikan UU Pengadilan Anak yang lama, harapannya adalah keadilan restoratif bagi pelaku anak dapat terpenuhi melalui alternatif metode pemeriksaan perkara yang disebut dengan diversi. Hal ini kemudian menimbulkan pertanyaan apakah hal tersebut telah mampu tercapai sejak diundangkannya UU SPPA.

Berdasarkan database pemasyarakatan akhir tahun 2015, jumlah anak yang berada pada LPKA/Lapas/Rutan dan bermasalah dengan hukum sebanyak 2.993 anak. Terdapat penurunan jumlah angka yang sangat signifikan dari sebelumnya yaitu 5.358 (data 2012-2014), yang mendapatkan putusan pidana penjara. ${ }^{30}$

Ini adalah salah satu indikator bahwa konsep keadilan restoratif (restorative justice) dan upaya diversi sebagaimana telah diberlakukannya UU nomor 11 tahun 2012 tentang Sistem Peradilan Pidana Anak (SSPA), memiliki dampak positif bagi anak yang berkonflik pada masalah hukum. ${ }^{31}$

Sebelum keberlakuan UU SPPA, terdapat banyak pelanggaran hak yang dialami oleh pelaku anak bahkan sejak sebelum dimulainya acara pengadilan. Restaria Hutabarat dari LBH Jakarta pada tahun 2012 memaparkan pada Tempo.com, hasil penelitian berjudul "Situasi Anak dalam Proses Hukum Pidana". Dalam penelitian itu, lembaganya mewawancarai 100 responden tahanan yang menjalani proses hukum pada periode Januari 2010-Januari 2012. Hampir semua tahanan anak mengalami kekerasan, bahkan pelecehan seksual, sebelum sampai di persidangan. Sebanyak 98 persen anak mengaku disiksa saat menjalani pemeriksaan, 97 persen mengaku dipukuli ketika penangkapan, dan 74 persen

\footnotetext{
30 http://itjen.kemenkumham.go.id/berita-utama/792-keadilan-restoratif-terhadap-anak-yangbermasalah-dengan-hukum diakses 21 September 2016

31 Id.
} 
dihajar saat di dalam tahanan. ${ }^{32}$ Dia mencontohkan hal yang dialami saat penangkapan dan pembuatan berita acara pemeriksaan. Sebanyak 54 responden mengaku pernah dibentak, 45 anak mengaku pernah dipukul, 37 dibentak, dan 27 dipukuli sampai timbul luka permanen pada tubuhnya. Berikutnya, sebanyak 30 anak ditodong dengan pistol, dan 11 anak disiksa dengan dijepit jarinya. Satu orang mengaku pernah dibakar. Selain itu, ada 8 anak yang mengaku pernah diraba pada bagian tubuhnya yang sensitif, dan 2 anak dipaksa melakukan oral seks. ${ }^{33}$

Penegak hukum yang diwawancarai pun mengakui bahwa bentuk kekerasan tersebut diperlukan guna mendapatkan pengakuan. Hal ini tidak sejalan dengan prinsip sistem akusator dalam sistem hukum acara pidana. Juga, sebelum ada UU SPPA belum terdapat sosialisasi dan pendidikan yang memadai bagi penegak hukum dalam menangani perkara yang melibatkan anak. Walaupun UU Pengadilan Anak saat itu sudah menyebutkan bahwa, misalnya, Hakim adalah Hakim anak dan tidak mengenakan toga selama pemeriksaan.

Setelah berlakunya UU SPPA, bentuk kekerasan seperti itu diharapkan tidak terjadi lagi walau sampai saat ini belum ada data yang membuktikan bahwa pemeriksaan pidana terhadap pelaku anak sudah bersih dari unsur kekerasan.

Keberhasilan UUSPPA meningkatkan perlindungan bagi $\mathrm{ABH}$ sesungguhnya dapat dioptimalkan dengan menghilangkan atau memperbaharui Pasal 7 ayat (2) UUSPPA mengenai batas 7 (tujuh) tahun antara tindak pidana yang wajib-diversi dan yang tidak. Pasal ini bertentangan dengan teori keadilan restoratif yang diusung UUSPPA itu sendiri.

Bahwa sesungguhnya tidak tepat pembedaan $\mathrm{ABH}$ yang melakukan tindak pidana yang diancam pidana penjara di bawah 7 (tujuh) tahun dan di atas 7 (tujuh) tahun. Konsekuensinya adalah bagi ABH yang melakukan tindak pidana dengan ancaman penjara 7 (tujuh) tahun atau lebih tidak mendapatkan fasilitas diversi dan kesempatan yang sama untuk disembuhkan, karena penegak hukumnya tidak

\footnotetext{
32 https://m.tempo.co/read/news/2012/04/12/173396497/lbh-hampir-semua-tahanan-anakdisiksa diakses 21 September 2016

33 Id.
} 
diwajibkan untuk itu. Jadi, baginya tetap beresiko terkena stigma negatif pemidanaan.

Itu artinya, tidak ada keadilan sosial yang menginginkan keseimbangan antar unsur masyarakat. ABH yang melakukan tindak pidana lebih dari atau sama dengan 7 (tujuh) tahun penjara bukan termasuk subyek dalam masyarakat di bawah naungan UUSPPA.

Anak pada hakekatnya tidak melakukan perilaku menyimpang. Jika anak ternyata melakukan perilaku menyimpang, termasuk di dalamnya perbuatan yang melawan hukum, berarti status mental anak tersebut perlu dievaluasi. Apalagi jika anak melakukan tindak pidana yang diancam pidana penjara lebih dari 7 (tujuh) tahun dan dianggap tindak pidana berat, maka anak yang bersangkutan perlu evaluasi yang hati-hati sebagai tindakan koreksi baginya, dan evaluasi yang komprehensif untuk memperbaiki tatanan masyarakat di sekitar anak tersebut.

Kesempatan evaluasi yang demikian terdapat dalam upaya diversi. Upaya diversi yang justru tidak diwajibkan baginya akibat adanya pembatasan diversi melalui Pasal 9 ayat (2) UUSPPA.

Juga, bahwa diversi adalah wajib tapi tetap berdasarkan pada kesepakatan pihak pelaku dan korban, menunjukkan bahwa diversi hanya wajib dalam hal pengupayaan oleh penegak hukum. Sedangkan, jika para pihak tidak sepakat akan melakukan diversi maka diversi tidak akan dijalankan. Hal ini menunjukkan UUSPPA justru tidak maksimal dalam terus mengembangkan upaya diversi.

Upaya diversi menjadi upaya yang optional, di mana proses acara pidana di pengadilan justru lebih bersifat wajib daripada diversi itu sendiri. Lebih tepat jika Pasal tentang diversi mengatur bahwa upaya diversi wajib tanpa terkecuali, dan proses acara pidana di pengadilan baru ditempuh jika proses musyawarah antar pelaku dan korban tidak berhasil.

\section{Penutup}

Pemerintah melalui instrumen UUSPPA sudah memberikan perlindungan hukum bagi anak, khususnya ABH. Perlindungan hukum bagi ABH dalam UUSPPA 
lebih baik dibandingkan dengan instrumen hukum acara pidana anak sebelum UUSPPA. Teori keadilan restoratif yang dianut UUSPPA untuk menggantikan teori keadilan retributif dalam hukum acara pidana anak yang lama, juga sesuai dengan prinsip keadilan sosial yang dianut Pancasila. Hal ini juga sejalan dengan teori pemidanaan relatif yang berusaha memperbaiki tindak pidana secara komprehensif dan bukan pidana sebagai pembalasan semata.

UUSPPA masih memiliki kekurangan dalam hal penerapan diversi guna mewujudkan tujuan pemidanaan dan teori keadilan restoratif tersebut. UUSPPA mengatakan diversi adalah wajib, namun meletakkan Pasal 7 ayat (2) yang membatasi kewajiban diversi itu sendiri, di mana diversi hanya wajib untuk tindak pidana yang diancam hukuman penjara di bawah 7 (tujuh) tahun. Kewajiban diversi ini pun ternyata adalah kewajiban bagi penegak hukum untuk menawarkan kepada para pihak agar menggunakan upaya diversi. Bukan wajib untuk melaksanakan diversi. Hal ini terlihat dari Pasal 9 ayat (2) bahwa pelaksanaan diversi tetap tergantung pada persetujuan pihak korban.

Pasal-pasal tersebut membatasi pelaksanaan diversi. Penggunaan upaya diversi seharusnya mutlak wajib tanpa dibatasi oleh kategori lamanya ancaman pidana penjara. Hal itu malah menunjukkan bahwa UUSPPA memberikan pertimbangan pengupayaan diversi atas tolak ukur obyek pidana, bukan memprioritaskan subyek pelaku pidana anak.

Untuk memaksimalkan pemenuhan keadilan restoratif dan kemanfaatan dari pemidanaan itu, maka Pasal 7 ayat (2) UUSPPA seharusnya diubah dengan menghapus pembatasan ancaman pidana penjara 7 (tujuh) tahun. Bahwa diversi diprioritaskan untuk tindak pidana di bawah 7 (tujuh) tahun adalah tidak sesuai dengan latar belakang dibuatnya UUSPPA dan prinsip yang melingkupinya.

Diversi sebaiknya mutlak diwajibkan untuk dilaksanakan, bukan hanya diupayakan, untuk setiap jenis tindak pidana anak. Jika proses musyawarah kemudian gagal, baru bisa dilanjutkan proses acara pidana konvensional. Hal ini tentunya juga sejalan dengan prinsip ultimum remedium dari hukum pidana. 
Hal yang demikian menurut hemat penulis adalah konsep paling ideal agar UUSPPA secara filosofis linear dengan teori keadilan restoratif dan teori pemidanaan relatif. Juga agar secara praktis UUSPPA dapat mengakomodasi perlindungan hukum bagi $\mathrm{ABH}$ secara maksimal.

\section{Daftar Pustaka}

\section{Buku}

C. Djisman Samosir, Sekelumit tentang Penologi dan Pemasyarakatan. Bandung: Nuansa Aulia, 2012.

H.R. Abdussalam dan Adri Desasfuryanto. Hukum Perlindungan Anak. Jakarta: PTIK, 2016

Lawrence M. Friedman. Sistem Hukum Perspektif Ilmu Sosial. Bandung: Nusa Media, 2011

Lilik Mulyadi. Hukum Acara Pidana Normatif, Teoretis, Praktik dan Permasalahannya. Bandung: Alumni, 2007.

Moeljatno. Asas-Asas Hukum Pidana. Jakarta: Rineka Cipta, 2008.

Muladi dan Barda Nawawi Arief. Bunga Rampai Hukum Pidana. Bandung: Alumni, 2007.

Munir Fuady dan Sylvia Laura L. Fuady. Hak Asasi Tersangka Pidana. Jakarta: Prenada Media Grup, 2015.

P.A.F. Lamintang dan Theo Lamintang. Hukum Penitensier Indonesia. Jakarta: Sinar Grafika, 2012.

\section{Internet}

Erasmus A.T. Napitupulu, Over kapasitas Lapas dan Rutan: Jumlah Penghuni dan Masalah utama, http://www.hukumpedia.com/erasmus70/over-kapasitaslapas-dan-rutan-jumlah-penghuni-dan-masalah-utama

Fajrin Recht, Pidana dan Pemidanaan, http://kitabpidana.blogspot.co.id/2012/04/pidana-dan-pemidanaan.html diakses 15 Agustus 2016

Sugi Arto, Dasar dan Tujuan Pemidanaan, http://artonang.blogspot.co.id/2015/02/dasar-dan-tujuanpemidanaan.html diakses 15 Agustus 2016

http://geotimes.co.id/indonesia-butuh-tambahan-lapas-khusus-anak/

http://www.hukumpedia.com/erasmus70/over-kapasitas-lapas-dan-rutan-jumlahpenghuni-dan-masalah-utama

http://itjen.kemenkumham.go.id/berita-utama/792-keadilan-restoratif-terhadapanak-yang-bermasalah-dengan-hukum 
http://www.kemenpppa.go.id/index.php/page/read/29/845/press-realese-anakberhadapan-dengan-hukum-abh-mesti-mendapat-perlindungan-khusus http://nasional.sindonews.com/read/1029405/13/lapas-anak-berubah-jadilembaga-pembinaan-khusus-anak-1438691149/2

http://poskotanews.com/2016/08/14/anak-dipidana-di-bawah-tujuh-tahun-tidakdimasukkan-ke-lapas/

http://smslap.ditjenpas.go.id/public/grl/current/monthly diakses 15 Agustus 2016 https://m.tempo.co/read/news/2012/04/12/173396497/lbh-hampir-semuatahanan-anak-disiksa

\section{Sumber Hukum Primer}

Undang-Undang Nomor 35 Tahun 2014 tentang Perubahan atas UU No. 23 Tahun 2012 tentang Perlindungan Anak

Undang-Undang No. 11 Tahun 2012 tentang Sistem Peradilan Pidana Anak.

Undang-Undang Nomor 23 tahun 2002 tentang Perlindungan Anak

Undang-Undang R.I Nomor 39 Tahun 1999, Hak Asasi Manusia, L.N.R.I Tahun 1999 No. 165

Undang-Undang Nomor 12 Tahun 1995 tentang Lembaga Pemasyarakatan

Undang-Undang Nomor 8 Tahun 1981 (LNRI 1981-76; TLNRI 3209)

Peraturan Pemerintah Republik Indonesia Nomor 65 tahun 2015 Tentang Pedoman Pelaksanaan Diversi dan Penanganan Anak yang Belum Berumur 12 (Dua Belas) Tahun.

PERMA RI Nomor 4 Tahun 2014 tentang Pedoman Pelaksanaan Diversi dalam Sistem Peradilan Pidana Anak

Convention on the Rights of the Child, Adopted and opened for signature, ratification and accession by General Assembly resolution 44/25 of 20 November 1989 entry into force 2 September 1990. 